\title{
DA MEDIAÇÃO E CONCILIAÇÃO EM AUDIENCIAS TRABALHISTAS NO CONTEXTO PANDÊMICO
}

Francislaine de Almeida Strasser, Nayara Maria Silvério da Costa Dallefi, Lícia Pimentel Marconi, André Soares Sartoro

Universidade do Oeste Paulista - UNOESTE, Presidente Prudente, SP. E-mail: fran_coimbra_@hotmail.com

\section{RESUMO}

Os direitos sociais são direitos fundamentais, com enaltecimento na Declaração Universal dos Direitos Humanos, ficando o Estado responsável por sua fiscalização e efetividade. Entretanto, é sabido que muitas vezes não ocorre seu cumprimento integral, motivo pelo qual a Justiça do Trabalho torna-se um órgão de suma importância para realizar a segurança jurídica não só dos direitos dos trabalhadores, como também para a análise do contraditório e ampla defesa, por parte dos empregadores. Como forma de solucionar este litígio entre as partes, um dos meios de grande valia para uma tentativa de pacificação deste litígio e uma possível satisfação dos direitos sociais não aplicados, é a conciliação e mediação, sendo que em relação a este último é o melhor a ser utilizado como terminologia correta, acrescentando o fato da Justiça do Trabalho ser a pioneira em sua aplicação no direito pátrio. Esse método também vem sendo de grande valia nos tempos atuais, proporcionando uma segurança jurídica entre as partes, diante a pandemia da COVID-19 e a necessidade de continuidade do trabalho do Poder Judiciário de maneira remota, observando ainda, que em relação a produção de provas, é divergente, mas em relação a mediação na audiência, não restar dúvida de ser um grandioso método a ser aplicado. Para alcançar os objetivos específicos, o método utilizado foi o dedutivo, partindo da premissa geral sobre o conceito de Mediação e Conciliação e para tanto, trazendo essa abordagem sobre os direitos sociais, como um direito fundamental e seus aspectos históricos.

Palavras-chave: Mediação. Conciliação. Direitos Sociais. Audiência inicial. COVID-19.

\section{MEDIATION AND CONCILIATION IN LABOR AUDIENCES IN THE PANDEMIC CONTEXT}

\section{ABSTRACT}

Social rights are fundamental rights, with praise in the Universal Declaration of Human Rights, being the State responsible for its supervision and effectiveness. However, it is well known that it is often not fully enforced, which is why the Labour Court becomes a very important body for achieving legal certainty not only for workers' rights, but also for analysing the contradictory and broad defence, by employers. As a means of resolving this dispute between the parties, conciliation and mediation are one of the most valuable ways of trying to pacify this dispute and of possibly satisfying social rights that have not been applied, and that in relation to the latter is the best to be used as correct terminology, adding the fact that Labor Justice is the pioneer in its application in the law of the fatherland. This method has also been of great value in the present times, providing legal certainty between the parties, in the face of the COVID-19 pandemic and the need for continuity of the work of the Judiciary Branch in a remote way, noting further, that in relation to the production of evidence, it is divergent, but in relation to mediation in the audience, there is no doubt that it is a grand method to be applied. To achieve the specific objectives, the method used was deductive, starting from the general premise on the concept of Mediation and Conciliation and for that, bringing this approach on social rights, as a fundamental right and its historical aspects.

Keywords: Mediate. Reconciliation. Law Social. Intial herning. COVID-19. 


\section{INTRODUÇÃO}

O presente trabalho visa tratar dos meios facilitadores de resolução dos processos judiciais na Justiça do Trabalho, principalmente diante o numeroso volume decorrentes da nova realidade que o mundo todo está enfrentando, decorrente das demissões em massas e problemas econômicos advindos da pandemia por conta da COVID-19.

Os direitos sociais é tema de grande avanço desde o início do século passado, principalmente após a Declaração Universal dos Direitos Humanos (DUDH) ${ }^{1}$ (1948), oportunidade em que ocorre uma maior reflexão sobre a necessidade de proteção social em nome do princípio da dignidade da pessoa humana e a necessidade de um respeito maior aos direitos fundamentais.

Os direitos humanos têm grande influência na aplicação dos direitos fundamentais pátrios e todo esse cenário também é aplicado no âmbito do direito do trabalho, lembrando ainda que não só os direitos humanos, mas todo o direito internacional e seus organismos possuem grande influência em nosso direito interno, a exemplo da Organização Internacional do Trabalho, por meio de suas convenções, recomendações e protocolos.

Por sua vez, os conflitos internos nas relações trabalhistas são judicializados ao órgão específico, que é a Justiça do Trabalho.

Não obstante, pelo desgaste emocional que um processo causa para as partes envolvidas, faz-se mister um olhar mais humano com aplicação de métodos para uma possível composição amigável entre essas partes.

Dentre esses métodos, está a conciliação, que é um eficaz meio para a solução dos conflitos, com o enfoque no presente trabalho da tentativa da mediação em audiência inicial, mesmo que seja na modalidade remota, pacificando assim as relações postas, ou na fase de execução.

Partindo dessas premissas introdutórias, se utilizou a partir de uma pesquisa histórico bibliográfica, o método dedutivo, para apontar a eficácia e segurança jurídica que pode proporcionar a tentativa de resolução das

\footnotetext{
${ }^{1}$ Sigla que foi atribuída pela Assembleia Geral das Nações Unidas como o ideal comum a ser atingido por todos os povos e todas as nações. Disponível em: http://www.dhnet.org.br/direitos/deconu/textos/integra.htm. Acesso em: 01 jul. 2020.
}

demandas trabalhistas, principalmente em tempos de pandemia, por intermédio da mediação, mesmo que seja na modalidade remota.

\section{MÉTODOS}

O método utilizado na presente pesquisa foi o dedutivo, partindo da premissa geral sobre o conceito de Mediação e Conciliação e para tanto, trazendo essa abordagem sobre os direitos sociais, como um direito fundamental e seus aspectos históricos. A partir de então a sua inserção dentro do direito do trabalho, principalmente na atualidade, em relação as audiências pela modalidade remota, em tempos de pandemia, como forma de segurança jurídica.

Sabe-se que a ciência é preciso para a vida humana como forma de compreensão das coisas e os seus fenômenos de modo que a utilização do método dedutivo se torna necessária, onde suas premissas apresentadas proporcionarão uma conclusão pautada na segurança jurídica em caso de sua aplicação (LAKATOS; MARCONI, 2000).

Deste modo, as premissas gerais se coadunam com o resultado encontrado da efetividade da mediação nas audiências trabalhistas, pela aplicação do método dedutivo, observado a partir de uma pesquisa bibliográfica e jurisprudencial.

\section{Direitos Fundamentais Sociais sob a perspectiva do Princípio da Fraternidade}

O texto constitucional além de implantar uma nova ordem jurídica no país passa a ser a figura central do sistema, dotada de forte carga valorativa, sendo que o seu papel primordial é a concretização dos direitos fundamentais. Assim, a Constituição passa a ter valor não somente pela sua hierarquia, mas pelo seu valor axiológico.

Nesse sentido, a lição de Konrad Hesse (1991, p. 15): 
A partir dessas considerações, deve-se enquadrar os direitos sociais como direitos fundamentais do homem. Entre nós, José Afonso da Silva (1999, p. 178-179), conceitua direitos sociais, sob a dimensão dos direitos fundamentais do homem que, para ele:

São prestações positivas proporcionadas pelo Estado direta ou indiretamente, enunciadas em normas constitucionais, que possibilitam melhores condições de vida aos mais fracos, direitos que tendem a realizar a igualização de situações sociais desiguais. São, portanto, direitos que se ligam ao direito da igualdade. Valem como pressuposto do gozo dos direitos individuais na medida em que criam condições materiais propícias ao aferimento da igualdade real, o que, por sua vez proporciona condição mais compatível com o exercício efetivo da liberdade.

O mesmo autor (SILVA, 2008, p. 183) traça as principais diferenças entre os direitos sociais e os direitos econômicos, explicitando que "direitos sociais disciplinam situações subjetivas pessoais ou grupais de caráter concreto, sendo que os direitos econômicos constituirão pressupostos de existência dos direitos sociais".

Ainda se encontra na Declaração Universal dos Direitos do Homem, em seus arts. 22 a $28^{2}$, a enumeração dos chamados direitos

\footnotetext{
${ }^{2}$ Todos os artigos enumerados estão no: http://www.dhnet.org.br/direitos/deconu/textos/integra.htm. Acesso em: 01 jul. 2020:

Artigo 22

Todo o homem, como membro da sociedade, tem direito à segurança social e à realização, pelo esforço nacional, pela cooperação internacional e de acordo com a organização e recursos de cada Estado, dos direitos econômicos, sociais e culturais indispensáveis à sua dignidade e ao livre desenvolvimento de sua personalidade.

Artigo 23

1) Todo o homem tem direito ao trabalho, à livre escolha de emprego, a condições justas e favoráveis de trabalho e à proteção contra o desemprego.

II) Todo o homem, sem qualquer distinção, tem direito a igual remuneração por igual trabalho.
}

econômicos, sociais e culturais. Tais direitos visam resguardar o cidadão comum das vicissitudes de uma convivência social carregada de desigualdades que dificultam e muitas vezes impedem o livre desenvolvimento de seus planos de vida. São direitos sociais do homem, como genericamente conhecidos, de acordo com os artigos mencionados: direito à segurança social, à satisfação dos direitos econômicos, sociais e culturais indispensáveis à dignidade da pessoa humana e ao livre desenvolvimento de sua personalidade; direitos ao trabalho, à escolha do trabalho, a condições satisfatórias de trabalho, à

III) Todo o homem que trabalha tem direito a uma remuneração justa e satisfatória, que lhe assegure, assim como a sua família, uma existência compatível com a dignidade humana, e a que se acrescentarão, se necessário, outros meios de proteção social.

IV) Todo o homem tem direito a organizar sindicatos e a neles ingressar para proteção de seus interesses. Artigo 24

Todo o homem tem direito a repouso e lazer, inclusive a limitação razoável das horas de trabalho e a férias remuneradas periódicas.

Artigo 25

I) Todo o homem tem direito a um padrão de vida capaz de assegurar a si e a sua família saúde e bem estar, inclusive alimentação, vestuário, habitação, cuidados médicos e os serviços sociais indispensáveis, e direito à segurança em caso de desemprego, doença, invalidez, viuvez, velhice ou outros casos de perda de meios de subsistência em circunstâncias fora de seu controle. II) A maternidade e a infância têm direito a cuidados e assistência especiais. Todas as crianças, nascidas dentro ou fora do matrimônio, gozarão da mesma proteção social.

Artigo 26

1) Todo o homem tem direito à instrução. A instrução será gratuita, pelo menos nos graus elementares e fundamentais. A instrução elementar será obrigatória. A instrução técnica

profissional será acessível a todos, bem como a instrução superior, esta baseada no mérito.

II) A instrução será orientada no sentido do pleno desenvolvimento da personalidade humana e do fortalecimento do respeito pelos direitos do homem e pelas liberdades fundamentais. A instrução promoverá a compreensão, a tolerância e amizade entre todas as nações e grupos raciais ou religiosos, e coadjuvará as atividades das Nações Unidas em prol da manutenção da paz.

III) Os pais têm prioridade de direito na escolha do gênero de instrução que será ministrada a seus filhos. Artigo 27

I) Todo o homem tem o direito de participar livremente da vida cultural da comunidade, de fruir as artes e de participar do progresso científico e de fruir de seus benefícios.

II) Todo o homem tem direito à proteção dos interesses morais e materiais decorrentes de qualquer produção científica, literária ou artística da qual seja autor. Artigo 28

Todo o homem tem direito a uma ordem social e internacional em que os direitos e liberdades estabelecidos na presente Declaração possam ser plenamente realizados. 
proteção contra o desemprego, a salário digno e à liberdade sindical; direito à limitação razoável da duração do trabalho, a férias, a descanso remunerado e ao lazer; direito a um nível de vida adequado que the assegure, assim como a sua família, a saúde, o bem-estar e, em especial, a alimentação, o vestuário, a moradia, a assistência médica e os serviços sociais necessários; direito à previdência e seguro social no caso de desemprego, enfermidade, invalidez, viuvez e velhice; direitos especiais à maternidade e à infância; direito à educação, à instrução técnica e profissional e à cultura; direito a uma ordem social e internacional em que os direitos fundamentais sejam plenamente efetivos.

De outro prisma, os arts. 1ㅇ e 2ㅇ da $\mathrm{DUDH}^{3}$ estabelecem a igualdade entre os homens e também um mesmo tratamento entre ambas classes de direitos: individuais e sociais, enquanto o art. $29^{4}$ estatui os deveres da pessoa para com a comunidade, a submissão somente à lei e a supremacia dos propósitos e princípios das Nações Unidas. E, por fim, o seu art. 30 afirma o princípio de interpretação da Declaração sempre em benefício dos direitos e liberdades nela proclamados.

No art. 6ạ da Constituição de $1988^{5}$ (BRASIL, 1988), estão presentes alguns dos direitos sociais, como a educação, saúde, alimentação, trabalho, moradia, lazer, segurança, previdência social, proteção à maternidade e à

\footnotetext{
${ }^{3}$ Artigo $1^{\circ}$ : Todos os seres humanos nascem livres e iguais em dignidade e em direitos. Dotados de razão e de consciência, devem agir uns para com os outros em espírito de fraternidade. Artigo $2^{\circ}$ : Todos os seres humanos podem invocar os direitos e as liberdades proclamados na presente Declaração, sem distinção alguma, nomeadamente de raça, de cor, de sexo, de língua, de religião, de opinião política ou outra, de origem nacional ou social, de fortuna, de nascimento ou de qualquer outra situação. Além disso, não será feita nenhuma distinção fundada no estatuto político, jurídico ou internacional do país ou do território da naturalidade da pessoa, seja esse país ou território independente, sob tutela, autônomo ou sujeito a alguma limitação de soberania. Disponível em: http://www.dhnet.org.br/direitos/deconu/textos/integra.htm. Acesso em: 01 jul. 2020.

${ }^{4}$ Artigo $29^{\circ} 1.0$ indivíduo tem deveres para com a comunidade, fora da qual não é possível o livre e pleno desenvolvimento da sua personalidade. 2.No exercício deste direito e no gozo destas liberdades ninguém está sujeito senão às limitações estabelecidas pela lei com vista exclusivamente a promover o reconhecimento e o respeito dos direitos e liberdades dos outros e a fim de satisfazer as justas exigências da moral, da ordem pública e do bem-estar numa sociedade democrática. 3.Em caso algum estes direitos e liberdades poderão ser exercidos contrariamente e aos fins e aos princípios das Nações Unidas. Disponível em: http://www.dhnet.org.br/direitos/deconu/textos/integra.htm. Acesso em: 01 jul. 2020.

${ }^{5}$ Artigo 60: São direitos sociais a educação, a saúde, o trabalho, o lazer, a segurança, a previdência social, a proteção à maternidade e à infância, a assistência aos desamparados, na forma desta Constituição.
}

infância, assistência aos desamparados, na forma da lei. A Constituição também apresenta uma ordem social com amplo universo de normas que enunciam programas, tarefas, diretrizes e fins a ser perseguidos pelo Estado e pela sociedade, como direito de todos e dever do Estado à saúde (art. $196^{6}$ ), às práticas desportivas (art. 2177), dentre outros.

Tais direitos fundamentais sociais ou direitos sociais vieram à tona com a nova conformação do Estado que deixou de ser liberal, como mero garantidor das liberdades individuais, para fornecer aos cidadãos prestações positivas para satisfação de suas necessidades básicas, o chamado Estado Democrático Social de Direito, como enuncia Ingo Wolfgang Sarlet (2012, p. 62):

No âmbito de um Estado
Social de Direito - o
consagrado pela nossa
evolução constitucional -
os direitos fundamentais
sociais constituem
exigência inarredável do
exercício efetivo das
liberdades e garantia da
igualdade de chances
(oportunidades) inerentes
à noção de uma
democracia e um Estado
de Direito de conteúdo
não meramente formal,
mas sim guiado pelo valor
da justiça material.

Assim, a Constituição Federal não deve ser ornamental, não se resume a um museu de princípios, não é meramente um ideário, mas reclama efetividade real de suas normas. $E$, sob esse ângulo, merece destaque o princípio fundante da República que destina especial proteção à dignidade da pessoa humana, o qual

\footnotetext{
${ }^{6}$ Artigo 196: A saúde é direito de todos e dever do Estado, garantido mediante políticas sociais e econômicas que visem à redução do risco de doença e de outros agravos e ao acesso universal e igualitário às ações e serviços para sua promoção, proteção e recuperação.

7 Artigo 217: É dever do Estado fomentar práticas desportivas formais e não formais, como direito de cada um, observados: I - a autonomia das entidades desportivas dirigentes e associações, quanto a sua organização e funcionamento;

II - a destinação de recursos públicos para a promoção prioritária do desporto educacional e, em casos específicos, para a do desporto de alto rendimento;

III - o tratamento diferenciado para o desporto profissional e o não profissional;

IV - a proteção e o incentivo às manifestações desportivas de criação nacional.
} 
se situa na matriz dos direitos fundamentais em nossa Constituição. Nesse sentido, Ingo Wolfgang Sarlet (2012, p. 62):

\begin{abstract}
A qualidade intrínseca e distintiva reconhecida em cada ser humano que o faz merecedor do mesmo respeito e consideração por parte do estado e da comunidade, implicando nesse sentido, um complexo de direitos e deveres que assegurem a pessoa tanto contra todo e qualquer ato de cunho degradante e desumano, como venham a garantir as condições existenciais mínimas para uma vida saudável, além de propiciar e promover sua participação ativa e corresponsável nos destinos da própria existência e da vida em comunhão com os demais seres humanos.
\end{abstract}

O Brasil atual enfrenta um momento que exige reflexões acerca da relação laboral, em especial no que diz respeito à flexibilização de direitos já conquistados em face da pandemia, em que os efeitos colaterais de um vírus demandam questionamentos sobre qual tipo de sociedade queremos ser, ou se queremos uma sociedade fraterna com um patamar mínimo civilizatório, com a garantia dos direitos sociais.

Hinkelammert (1988) ensina que não se pode pensar em utopias ingênuas, e sim no que é possível fazer a partir da tecnologia, sem perder o enfoque no respeito ao ser humano, satisfazendo as suas necessidades básicas. Boaventura de Sousa Santos (1997) acrescenta o multiculturalismo como meio de transformar o localismo globalizado dos direitos humanos em cosmopolitismo, como os diálogos de organização Sul-Sul e organizações transnacionais de direitos humanos. O autor usa a expressão "localismo globalizado" para explicar que se vive num mundo de globalização com localização, como ocorreu com a língua inglesa e sua propagação enquanto língua global, o que implicou a localização de outras línguas globais, como a francesa. E o mesmo ocorreu com o fenômeno da globalização do fast food.
A partir do reconhecimento de que as culturas são incompletas e problemáticas, nas concepções de direitos humanos, Santos (1997) propõe um diálogo intercultural pela hermenêutica diatópica numa política progressista e emancipatória. Tal diálogo possibilitaria uma concepção mestiça de direitos humanos, sem falsos universalismos, numa troca de diferentes culturas (topoi).

Seria possível o diálogo sob a ótica da fraternidade, em que o ser humano seja capaz de interagir, de dialogar, de compreender os outros e suas diversidades, num espaço de cidadania culturamente não homogêneo e marcado pela insegurança, medo e preocupação, a respeito do vírus COVID-19, altamente contagioso. (BAGGIO, 2009).

Para o ministro Reynaldo Soares da Fonseca do egrégio Superior Tribunal de Justiça, vive-se um desastre humanitário, provocado por uma pandemia que tornou ou tornará todos os seres humanos mais pobres em termos materiais. O momento, exige a construção de homens fraternos, nos moldes do artigo 3ㅇ da Lei Maior ${ }^{8}$ (BRASIL, 1988), e de uma sociedade mediadora.

Efetivamente, o caminho da solidariedade, o caminho daquilo que estamos propondo como um princípio esquecido para que seja reavivado o princípio da fraternidade -, é o caminho do século $\mathrm{XXI}$, especialmente depois da pandemia. Esperamos que todos consigamos ultrapassar essa fase e possamos voltar a discutir políticas públicas. (COVID19,2020)

Ademais, Raffaele di Giorgi enfatizou a importância da fraternidade no contexto em que estamos inseridos, qual seja de uma modernidade tardia, caracterizada pela tridimensionalidade da segurança, imergida no medo da alteridade da desigualdade enfeixada na sociedade capitalista, a população, que é

\footnotetext{
${ }^{8}$ Art. 3ㅇ Constituem objetivos fundamentais da República Federativa do Brasil:

I - construir uma sociedade livre, justa e solidária;

II - garantir o desenvolvimento nacional;

III - erradicar a pobreza e a marginalização e reduzir as desigualdades sociais e regionais;

IV - promover o bem de todos, sem preconceitos de origem, raça, sexo, cor, idade e quaisquer outras formas de discriminação.
} 
ameaçada por si mesma e o território não tem mais limites, trazendo a lume a importância do papel do Direito para não resultar numa crise dos direitos fundamentais, notadamente os sociais. (COVID-19, 2020).

Nesse sentido:

A exceção cria um espaço de decisão no qual se suspende o direito para se realizar a moral, a política e outros interesses, ou seja, quando o direito é violado, seja individualmente - numa relação concreta - ou em termos gerais - podendo atingir todos de forma indiferenciada -, nós temos um quadro em que o fundamento da decisão como exceção justifica a tese de suspensão do direito, naquilo que os garantistas chamam de crise dos direitos fundamentais. (COVID-19, 2020).

Assim, a compreensão da realidade pandêmica deve ser a partir da fraternidade, para a concretização dos direitos sociais, numa ligação entre o Estado e o mercado, pela implementação de políticas públicas, voltadas à conciliação e mediação, que dizem respeito aos próprios direitos fundamentais.

2 Mediação dos direitos laborais: possibilidades e parâmetros a partir dos princípios do direito do trabalho.

A vida em sociedade requer $o$ estabelecimento de condutas como forma de pacificação dos conflitos inerentes do convívio de todas as pessoas. Justamente por isso, desde os primórdios da sociedade existem inúmeros meios, tais como as leis, os costumes, os princípios e até mesmo as jurisprudências, também considerados como fontes do direito.

Entretanto, é fato que outros meios também se fizeram presentes como a autotutela, também conhecido como a realização de justiça com as próprias mãos, meio este que não é mais admissível, sendo que o meio regulador entre as relações é a norma jurídica, conforme ensina Miguel Reale ao dizer "onde está o homem, aí está a regra; onde há convivência, há norma”. (REALE, 2005).
Há também os denominados meios facilitadores para a solução de conflito, também conhecidos como meios alternativos, não só no Brasil, mas em todo o direito estrangeiro, sendo os mais comuns a conciliação, a arbitragem e a mediação.

Todos esses meios estão muito em voga, diante o afogo do Poder Judiciário, decorrente de inúmeras demandas judiciais, e a dificuldade de realizar a solução de todos os processos, principalmente decorrente das dificuldades de todo o mundo, oriundo dos efeitos da pandemia da COVID-19.

Em que pese toda a busca de utilização desses meios como forma de solução de conflito, é fato, que eles sempre existiram muito antes do processo digital, conforme registros históricos e a sua utilização tem uma eficácia prática favorável.

\subsection{Meios facilitadores de solução de conflitos}

Sobre os meios de facilitação mais frequentes no direito, temos atualmente a arbitragem, conciliação e medicação. De todos os meios extrajudiciais de solução de conflito, o instituto da arbitragem é o mais antigo, conforme relatos literários, com registros antes de Cristo, onde os conflitos eram submetidos ao líder da região é que decidia pela melhor solução, após ser procurado pelas partes. (GUILHERME, 2016)

Ao longo do século $X X$ este instituto foi se desenvolvendo e amadurecendo até que em 1996 foi publicada a Lei da Arbitragem (LEI no 9.307/96) e em 2015 teve algumas alterações com a entrada em vigência da Lei 13.129/15 NCPC - quando o legislador buscou ampliar a aplicação da arbitragem, falando ainda sobre a escolha dos árbitros quando as partes recorrem a algum órgão arbitral, sobre a interrupção da prescrição pela instituição da arbitragem, sobre a concessão de tutelas cautelares e de urgência nos casos de arbitragem e ainda fala sobre a carta arbitral e a sentença arbitral. (CAVALCANTE, 2015)

Segundo o ilustre Professor Doutor Carlos Alberto Carmona, o instituto da "arbitragem" se define como sendo um meio heterocompositivo de solução de conflitos, diferente da conciliação e mediação pois este são meios de autocomposição, e define como "um mecanismo privado de solução de litígios, através do qual um terceiro, escolhido pelos litigantes, impõem a sua decisão, que deverá ser cumprida pelas partes". (CARMONA, 2009, p. 31) 
Ainda quanto ao instituto da arbitragem,

mas na esfera trabalhista, a Lei 13.467/2017 intitulada de Reforma Trabalhista, trouxe inovações ao permitir expressamente a aplicação da arbitragem ao incluir o art 507-A, que prevê a possibilidade, nos contratos individuais de trabalho, de ser pactuada, entre empregador e empregado, cláusula compromissória de arbitragem, desde que a remuneração do empregado seja superior a duas vezes o limite máximo estabelecido para os benefícios do Regime Geral da Previdência Social, ou seja, desde que o trabalhador tenha remuneração no valor de $\mathrm{R} \$ 12.867,14$ (para o ano de 2021) ${ }^{9}$. (BRASIL, 1943)

Inobstante as imposições legais, em que a opção supracitada deve ser escolhida de forma expressa pelo empregado por sua iniciativa ou através de sua concordância nos termos da lei, no sentido de garantir a liberdade de escolha por parte do empregado em submeter seu contrato de trabalho a arbitragem ou não, fato é que foi incorporada à legislação trabalhista o meio da arbitragem como forma de solução de conflito.

São notórios e perceptíveis os benefícios da arbitragem no âmbito trabalhista, tais como a celeridade na solução do litígio, considerando o abarrotamento de processos no judiciário.

Mais adiante, no texto trabalhista, podese encontrar outros direitos passíveis de serem objeto de solução de litígio através da arbitragem, como o previsto no art. $611-\mathrm{A}^{10} \mathrm{da}$ CLT (BRASIL, 1943), também fruto da reforma trabalhista, onde o legislador no caput dispõe que a convenção coletiva ou o acordo coletivo de trabalho tem prevalência sobre a lei, quando, entre outros, dispuser sobre os direitos elencados nos seus incisos.

Assim como o art. 611-B da CLT ${ }^{11}$ (BRASIL, 1943) que enumera o rol de direitos que não

\footnotetext{
9 Considerando que o teto dos benefícios pagos pelo Instituto Nacional do Seguro Social (INSS) passa a ser de R\$ 6.433,57. Disponível em: https://www.gov.br/pt-br/noticias/trabalho-eprevidencia/2021/01/beneficios-acima-do-minimo-tem-reajuste-de545\#: :text=0\%20reajuste\%20vale\%20desde\%201\%C2\%BA,R\%24\%2 06.101\%2C06). Acesso: 28 jul.2020.

${ }^{10}$ Artigo 611-A: A convenção coletiva e o acordo coletivo de trabalho têm prevalência sobre a lei quando, entre outros, dispuserem sobre.

${ }^{11}$ Art. 611-B. Constituem objeto ilícito de convenção coletiva ou de acordo coletivo de trabalho, exclusivamente, a supressão ou a redução dos seguintes direitos: (Incluído pela Lei no 13.467, de 2017)

I - normas de identificação profissional, inclusive as anotações na Carteira de Trabalho e Previdência Social; (Incluído pela Lei no 13.467, de 2017)
}

II - seguro-desemprego, em caso de desemprego involuntário; (Incluído pela Lei no 13.467, de 2017)

III - valor dos depósitos mensais e da indenização rescisória do Fundo de Garantia do Tempo de Serviço (FGTS); (Incluído pela Lei no 13.467, de 2017)

IV - salário mínimo; (Incluído pela Lei no 13.467, de 2017)

V - valor nominal do décimo terceiro salário; (Incluído pela Lei no 13.467, de 2017)

VI - remuneração do trabalho noturno superior à do diurno; (Incluído pela Lei no 13.467, de 2017)

VII - proteção do salário na forma da lei, constituindo crime sua retenção dolosa; (Incluído pela Lei no 13.467, de 2017)

VIII - salário-família; (Incluído pela Lei no 13.467, de 2017)

IX - repouso semanal remunerado; (Incluído pela Lei no 13.467, de 2017)

X - remuneração do serviço extraordinário superior, no mínimo, em $50 \%$ (cinquenta por cento) à do normal; (Incluído pela Lei № 13.467, de 2017)

XI - número de dias de férias devidas ao empregado; (Incluído pela Lei $n$ o 13.467, de 2017)

XII - gozo de férias anuais remuneradas com, pelo menos, um terço a mais do que o salário normal; (Incluído pela Lei no 13.467, de 2017)

XIII - licença-maternidade com a duração mínima de cento e vinte dias; (Incluído pela Lei no 13.467, de 2017)

XIV - licença-paternidade nos termos fixados em lei; (Incluído pela Lei no 13.467, de 2017)

XV - proteção do mercado de trabalho da mulher, mediante incentivos específicos, nos termos da lei; (Incluído pela Lei no 13.467, de 2017)

$\mathbf{X V I}$ - aviso prévio proporcional ao tempo de serviço, sendo no mínimo de trinta dias, nos termos da lei; (Incluído pela Lei no 13.467, de 2017)

XVII - normas de saúde, higiene e segurança do trabalho previstas em lei ou em normas regulamentadoras do Ministério do Trabalho; (Incluído pela Lei no 13.467, de 2017)

XVIII - adicional de remuneração para as atividades penosas, insalubres ou perigosas; (Incluído pela Lei no 13.467, de 2017)

XIX - aposentadoria; (Incluído pela Lei $n=13.467$, de 2017)

XX - seguro contra acidentes de trabalho, a cargo do empregador; (Incluído pela Lei no 13.467, de 2017)

XXI - ação, quanto aos créditos resultantes das relações de trabalho, com prazo prescricional de cinco anos para os trabalhadores urbanos e rurais, até o limite de dois anos após a extinção do contrato de trabalho; (Incluído pela Lei $n$ o 13.467, de 2017)

XXII - proibição de qualquer discriminação no tocante a salário e critérios de admissão do trabalhador com deficiência; (Incluído pela Lei no 13.467, de 2017)

XXIII - proibição de trabalho noturno, perigoso ou insalubre a menores de dezoito anos e de qualquer trabalho a menores de dezesseis anos, salvo na condição de aprendiz, a partir de quatorze anos; (Incluído pela Lei no 13.467, de 2017)

XXIV - medidas de proteção legal de crianças e adolescentes; (Incluído pela Lei no 13.467, de 2017)

XXV - igualdade de direitos entre o trabalhador com vínculo empregatício permanente e o trabalhador avulso; (Incluído pela Lei $\mathrm{n}$ ㅇ 13.467, de 2017)

$\mathbf{X X V I}$ - liberdade de associação profissional ou sindical do trabalhador, inclusive o direito de não sofrer, sem sua expressa e prévia anuência, qualquer cobrança ou desconto salarial estabelecidos em convenção coletiva ou acordo coletivo de trabalho; (Incluído pela Lei no 13.467, de 2017)

XXVII - direito de greve, competindo aos trabalhadores decidir sobre a oportunidade de exercê-lo e sobre os interesses que devam por meio dele defender; (Incluído pela Lei no 13.467, de 2017)

XXVIII - definição legal sobre os serviços ou atividades essenciais e disposições legais sobre o atendimento das necessidades inadiáveis da comunidade em caso de greve; (Incluído pela Lei no 13.467 , de 2017)

XXIX - tributos e outros créditos de terceiros; (Incluído pela Lei no 13.467, de 2017) 
podem ser objeto de redução ou supressão em acordo ou convenção coletiva.

Do que se conclui que os direitos previstos no art. 611-A da CLT (BRASIL, 1943) podem ser submetidos a arbitragem, já que foram objeto de acordo entre a partes envolvidas.

Em conseguinte, outro meio de solução de conflito é a conciliação, que possui embora muitos tratam em conjunto com a mediação, diferem-se um do outro. A conciliação possui objetivos e procedimentos muito semelhantes à mediação, focos principais deste trabalho, e rotineiramente utilizada nos processos judiciais, principalmente no âmbito trabalhista, inclusive como proposta obrigatória nos dissídios individuais e coletivos.

A Conciliação, como método de resolução de conflito, busca a obtenção de um acordo amigável entre as partes em litígio, por meio de concessões mútuas com a participação de um terceiro que atua de forma sugestiva, com forte carga indutiva a partir de proposições e sugestões de acordo de forma que cada uma das partes, voluntariamente, ceda em suas pretensões até alcançarem um meio termo satisfatório à ambas. Segundo PEREIRA (2015, s. p):

$$
\begin{aligned}
& \text { A conciliação é uma forma } \\
& \text { de resolução de conflitos, } \\
& \text { onde um terceiro, neutro } \\
& \text { e imparcial, chamado } \\
& \text { conciliador, facilita a } \\
& \text { comunicação entre } \\
& \text { pessoas que mantém uma } \\
& \text { relação pontual na busca } \\
& \text { de seus interesses e na } \\
& \text { identificação de suas } \\
& \text { questões, através de sua } \\
& \text { orientação pessoal e } \\
& \text { direta, buscando um } \\
& \text { acordo satisfatório para } \\
& \text { ambas. }
\end{aligned}
$$

A desembargadora Maria Lúcia Ribeiro de Castro Pizzotti Mendes, do TJ-SP, brilhantemente conceitua a conciliação como "uma forma nova, ágil e extremamente diferenciada de prestar-se a jurisdição, trazendo as partes para uma audiência. Na presença do conciliador,

XXX - as disposições previstas nos arts. 373-A, 390, 392, 392-A, 394, 394-A, 395, 396 e 400 desta Consolidação. (Incluído pela Lei no 13.467, de 2017)

Parágrafo único. Regras sobre duração do trabalho e intervalos não são consideradas como normas de saúde, higiene e segurança do trabalho para os fins do disposto neste artigo. (Incluído pela Lei no 13.467, de 2017) conversam entre si e farão a proposta. Se aceita, a proposta é homologada no mesmo dia pelo juiz, pondo fim ao processo, sem que haja recurso ou qualquer tipo de burocracia (PIZZOTTI apud ERDELYI, 2005).

Interessante destacar, e inclusive é motivo sempre de confusão, que a conciliação é um ato que tem o foco no objetivo das partes em resolver um litígio, portanto visa que as partes cheguem a um acordo, e este processo de conciliação se conclui com o resultado que é a transação, o acordo em si.

Além disso, a conciliação mescla características de mediação e arbitragem, sendo que o conciliador possui um papel muito mais ativo na solução do conflito do que o mediador, entretanto com atividade bem menor que o árbitro, atua, portanto, de maneira mais incisiva na questão, porém a decisão fica a cargo das partes, sendo o conciliador um facilitador que irá encaminhar as partes para que estas, cheguem a um acordo. Nesse sentido, o CNJ (Conselho Nacional de Justiça) posiciona como:

Um meio alternativo de resolução de conflitos em que as partes confiam a uma terceira pessoa (neutra), o conciliador, a função de aproximá-las e orientá-las na construção de acordo. O conciliador é uma pessoa da sociedade que atua de forma voluntária e após treinamento específico, como facilitador do acordo entre os envolvidos, criando um contexto propício ao entendimento mútuo, à aproximação de interesses e à harmonização das relações (CNJ, 2010).

Cabe ainda também considerar um importante ponto ao estudar o instituto da conciliação, que é a distinção entre conciliação judicial e extrajudicial.

A judicial ocorre durante o decorrer de um processo e se dá para aquele processo em específico. É uma tentativa do judiciário, numa atividade conflituosa, de obter um acordo de vontade das partes sobre o objeto em litígio e o referido acordo é homologado pelo juiz; também pode ocorrer quando as partes apresentam uma proposta de acordo junto ao juiz, pleiteando a 
homologação; necessariamente haverá uma decisão homologatória com relação a conciliação apresentada, com natureza de título executivo judicial podendo ser utilizado pelas partes para garantir seu cumprimento.

Já a extrajudicial é a que ocorre por meio de um contrato, fora do âmbito judicial e que a lei denomina como transação. Neste contrato as partes se conciliam sobre determinada matéria mediante concessões mútuas. Tal acordo tem a formalidade escrita e conta com o acordo de ambas as partes além de testemunhas, formando um título executivo extrajudicial.

Assim, percebe-se que a conciliação em ambos os casos, tem o objetivo de pôr fim ao litígio, sendo que no caso da judicial o processo já se iniciou e ocorre como uma das fases do processo e na extrajudicial o processo não teve início e as partes podem chegar a um acordo mais rápido e, caso não cheguem a este acordo ou descumpram o acordo firmado, poderá ainda buscar a solução pela via judicial, podendo até mesmo ser utilizada na Justiça do Trabalho.

Como determinação legal, e princípio trabalhista, a conciliação no processo do trabalho é uma etapa inicial e obrigatória, posto que a CLT (BRASIL, 1943) disciplina no art. $764^{12}$ que os dissídios individuais ou coletivos submetidos à apreciação da Justiça do Trabalho serão sempre sujeitos à conciliação; o legislador determina expressamente que o juiz é obrigado a empregar todos os meios necessários para que as partes cheguem a uma solução através de uma conciliação, desde que o acordo não venha a ferir direitos e garantias indisponíveis.

Vai além ainda o legislador ao dispor no $\S$ 10 do mesmo artigo que "para os efeitos deste artigo, os juízes e Tribunais do Trabalho empregarem sempre os seus bons ofícios e persuasão no sentido de uma solução conciliatória dos conflitos", sendo que 0 § 2 은 dispõe que "não havendo acordo, o juízo conciliatório converter-se-á obrigatoriamente em arbitral, proferindo decisão na forma prescrita neste Título".

\footnotetext{
12 Art. 764 - Os dissídios individuais ou coletivos submetidos à apreciação da Justiça do Trabalho serão sempre sujeitos à conciliação.

$\S 1$ ㅇ - Para os efeitos deste artigo, os juízes e Tribunais do Trabalho empregarão sempre os seus bons ofícios e persuasão no sentido de uma solução conciliatória dos conflitos.

$\S 2$ 2 - Não havendo acordo, o juízo conciliatório converter-se-á obrigatoriamente em arbitral, proferindo decisão na forma prescrita neste Título.

§ 3ㅇ - É lícito às partes celebrar acordo que ponha termo ao processo, ainda mesmo depois de encerrado o juízo conciliatório.
}

Por fim, o $\S$ 3o do mesmo dispositivo afirma ser "lícito às partes celebrar acordo que ponha termo ao processo, ainda mesmo depois de encerrado o juízo conciliatório (BRASIL, 1943).

Dessa forma, a conciliação vem tornandose um dos meios extrajudiciais de soluções de conflitos (MESCs) mais utilizados na justiça do trabalho, acrescentando a necessidade de enfatizar sobre a Comissão de Conciliação Prévia.

A CLT, nos artigos 625-A à 625-H, dispõe sobre a Comissões de Conciliação Prévia (CCP), instituto caracterizado como "um organismo jurídico de natureza heterocompositiva, em que as partes respectivas, através de atos não jurisdicionais, buscam, mediante comum acordo, solucionar conflitos individuais trabalhistas, existentes ou na iminência de existir". (PASSOS, 2003, p.37)

Segundo o texto legal, as CCP's (Comissões de Conciliação Prévia) podem ser instituídas no âmbito empresarial e interempresarial, ou seja, por uma ou várias empresas em conjunto, como também podem ser instituídas pelo Sindicato de determinada categoria, sendo que nesse caso as normas de funcionamento devem estar definidas na convenção ou acordo coletivo, nos termos dispostos no art 625-C da CLT.

A dúvida surgida, com a inserção da Comissão de Conciliação Prévia (CCP) no diploma legal foi quanto a obrigatoriedade de utilização, como pressuposto para a distribuição da ação trabalhista, nos casos em que não houver conciliação prévia, dúvida superada com a decisão do STF em agosto de 2018 a partir das ADI's de no 2139, 2160 e 2237 propostas, no sentido da inconstitucionalidade quanto a qualquer forma de restrição ao acesso à justiça, por força do art 5ㅇ, XXXV da CFRB/88, afastando assim a obrigatoriedade de submeter à CCP para o ajuizamento de uma reclamação trabalhista.

Nesse sentido, as CCP's, em que pese todo o propósito inicial quando da recepção à CLT, passou a ter uma natureza de tentativa extrajudicial de conciliação, e, portanto, de título executivo extrajudicial, nos termos do art 625-E da CLT.

Por fim, tem-se a mediação, com origem com os dizeres Aristóteles, com vistas à uma justiça corretiva nas transações entre os indivíduos, de forma voluntária; de acordo com o pensador "a mediação é um princípio fundamental para um juiz" (ARISTÓTELES, 1987, S.P.). 
Para BITTAR (2002, p. 38), "a solução para os conflitos que decorrem do desentendimento humano, pode dar-se por força da ética ou por força do direito que pode intervir para pacificar as relações humanas."

Como instituto jurídico, a Mediação encontra-se regulamentada no Brasil pela Lei no 13.140/2015, como método autocompositivo onde as partes são protagonistas da solução, auxiliadas por uma terceira pessoa na qualidade de Mediador, que atua como facilitador da comunicação, de postura independente e imparcial, que não vai julgar, todavia utiliza-se de técnicas e métodos para estimular que as partes apresentem soluções criativas no sentido de resolver o conflito instado.

Nas palavras de CALMON (2007, p. 144);

A principal distinção entre os dois mecanismos não reside em seus dirigentes, mas sim no método adotado: enquanto $o$ conciliador manifesta sua opinião sobre a solução justa para o conflito e propõe os termos do acordo, o mediador atua com um método estruturado em etapas sequenciais, conduzindo a negociação entre as partes, dirigindo o procedimento, mas abstendo-se de assessorar, aconselhar, emitir opinião e de propor fórmulas de acordo.

Pressupõe, portanto, um mediador capacitado, conforme bem destacado no parágrafo único do art 10 da Lei 13.140/2015 (BRASIL, 2015b) ao dispor que a mediação consiste na "atividade técnica exercida por terceiro imparcial sem poder decisório, que, escolhidos ou aceito pelas partes, as auxilia e estimula a identificar ou desenvolver soluções consensuais para a controvérsia".

A mediação encontra-se lastreada pelos princípios da imparcialidade do mediador, isonomia entre as partes, oralidade, informalidade, autonomia da vontade, busca do consenso, confidencialidade e boa-fé.

O ordenamento trabalhista no Brasil experimentou recente revisão a partir da lei 13.467/2017, com entrada em vigência em
11/11/2017, trazendo relevantes alterações e avanços tanto no aspecto material quanto no aspecto do processo do trabalho; e, em acompanhamento à marcha contemporânea, também revisitou os institutos relacionados às soluções alternativas de conflitos, incentivando o diálogo e a responsabilidade social para as partes negociarem, dentro do possível, seus próprios interesses.

Deste modo, o método aplicado entre a conciliação e a mediação são os mesmos, porém, a conciliação se distingue pelo fato de que o conciliador interfere na relação desarmoniosa, para que, ambas as partes cheguem a um acordo de vontades, enquanto na mediação, não é necessário a intervenção do mediador, para que as partes cheguem a um acordo, sendo ele apenas um ouvinte-facilitador da conversa, enquanto as partes se decidem entre si.

Em outras palavras, na conciliação, conciliador atua analisando a controvérsia em conjunto com as partes, sugerindo soluções, incentivando o acordo, intervindo nas controvérsias com suas opiniões e existe um objetivo claro e pré-estabelecido que é de chegar a um acordo por meio de concessões entre as partes envolvidas no conflito.

Já na mediação o procedimento é nãoadversarial, visando a autocomposição entre as partes, o mediador não julga, não intervém na decisão das partes, mas sim acompanha o entendimento delas.

O papel do mediador é de um facilitador da comunicação entre os envolvidos visando ajudá-los a compreender a complexidade da controvérsia e sua transformação numa outra situação melhor, procurando, assim, fazer a "terapia do vínculo conflitivo".

Segundo lições do mestre WATANABE (2014, p. 38): “a mediação, desde que bem organizada e praticada com qualidade, é um poderoso instrumento de estruturação melhor da sociedade civil. Por meio dela, vários segmentos sociais poderão participar da mencionada obra coletiva, de construção de uma sociedade mais harmoniosa, coesa e com acesso à ordem jurídica justa."

Com base em uma breve análise na doutrina sobre o tema da mediação, observa-se algumas escolas de pensamento que abordam o tema e disseminam técnicas diferentes.

As mais comuns são as escolas da mediação facilitativa, mediação avaliativa, mediação transformativa e mediação circular- 
narrativa; conhecidas também por nomenclaturas diversas, todavia regidas pelos mesmos princípios.

A escolha de qual seguir, depende diretamente do tipo de caso em conflito, da realidade econômica e social dos litigantes e diversos outros fatores, sendo que o modo de atuação do mediador, pode e deve variar de acordo com o andamento da mediação, caso perceba-se que a forma como se está atuando, não está dando resultado.

A mediação facilitativa, conhecida também como Escola Tradicional Linear de Harvard, se caracteriza-se pela atuação do mediador durante o andamento das sessões no sentido de buscar facilitar o diálogo entre as partes, para que todos alcancem seus objetivos e tenham a sensação real de que o que for acordado, será bom para todos, sólido, duradouro.

Segundo Roberto Portugal Bacellar: "é um desdobramento da negociação baseada em princípios, tem um processo estruturado linearmente em fases bem definidas e tem por propósito o de restabelecer a comunicação entre as partes para identificar os interesses encobertos pelas posições para com isso alcançar um acordo" (BACELLAR, 2012, p. 202).

Na mediação avaliativa, o mediador tem uma postura mais incisiva, mas sem deixar perceber as partes, que ele os está influenciando para isso o mediador necessita desenvolver técnicas em que ele não se deixe influenciar pelo meio e pelo comportamento das partes. 0 mediador faz mais sugestões, por isso este tipo de escola de mediação, por vezes é confundida com a conciliação. Comumente o mediador nesta situação se utiliza de uma expectativa de como o caso seria resolvido se estivesse sendo discutido dentro do âmbito judicial e expõe isto às partes, para que elas saibam as questões jurídicas envolvidas.

A mediação transformativa tem como foco buscar a solução mais ideal para a solução do conflito entre as partes, direcionando-se para a origem do problema acreditando-se ser a única forma de se evitar que novos imbróglios surjam no decorrer da relação entre as partes. Nesta escola, o mediador não impõe regras as partes, deixam-nas livres para o desenvolvimento do processo a cada passo.

Por último, a mediação circular-narrativa tem o foco na história que cada parte conta durante as sessões de mediação. Com estas informações, o mediador desconstrói, ou seja, leva para o início de todo o conflito existente entre as partes e durante este percurso vai "desatando os nós" que surgiram na relação passando a reconstruir o caminho, sob uma nova linguagem, mostrando os passos que as partes deram durante este percurso que levaram aos problemas, deixando isso de forma evidente às partes e sempre destacando que o alvo é o problema em questão e não a outra parte, de modo que ambas tirem o foco do problema da pessoa do outro lado.

O termo Mesc - Meios alternativos de solução de conflitos - para muitos soa como uma inovação, todavia não é nenhuma novidade, tratando-se de práticas que já permeiam vários ordenamentos jurídicos, incluindo o Brasil, sendo que somente no século XX é que a mediação teve sua prática mais definida e passou a ser utilizada de maneira mais assertiva, juntamente com outros meios extrajudiciais de conflitos.

Conforme já visto anteriormente, vários são os registros de aplicação de meios alternativos para solução de conflitos na História do Brasil, como tratado das Tordesilhas, Ordenações Filipinas, primeiras constituições e legislações infraconstitucionais, tendo como destaque a previsão legal no art $3 \circ$, § $3 \circ$ do CPC (BRASIL, 2015a) $)^{13}$ onde expressamente atribui o dever de dos magistrados, membros do Ministério Público, defensores públicos e advogados estimularem a conciliação, mediação e outros métodos de solução de conflitos inclusive no curso do processo judicial.

Ou seja, de forma clara, o ordenamento jurídico passou a obrigar a todos os operadores do direito a se adaptarem aos novos tempos e procurarem a melhor forma de solucionar um litígio, de forma rápida, justa, trazendo benefícios às partes, que somado à sobrecarga de ações nas vias judiciárias e crescentes demandas de questões de menor complexidade a cargo dos juizados, com base na Lei 9099/95 sinalizam cada vez mais pela busca de solução pelos meios alternativos.

É nesse contexto, social e jurídico, que deu início à discussão para a criação da chamada

\footnotetext{
${ }^{13}$ Art. 3ำ Não se excluirá da apreciação jurisdicional ameaça ou lesão a direito.

§ 3 A conciliação, a mediação e outros métodos de solução consensual de conflitos deverão ser estimulados por juízes, advogados, defensores públicos e membros do Ministério Público, inclusive no curso do processo judicial.
} 
lei da mediação, Lei № 13.140/15, tendo como marco quanto às inovações legislativas no âmbito das soluções de conflitos a Resolução do CNJ no 125 de 29 de novembro de 2010 , que de forma singular se preocupou com a criação de políticas públicas onde se deveria realizar programas e ações que incentivassem todos os braços do poder judiciário a realizar a estimular a autocomposição de conflitos, criação de CEJUSCS (Centros Judiciários de Solução de Conflitos e Cidadania), incentivar o diálogo das partes. (NUNES, 2016)

Com a entrada em vigência do Código de Processo Civil (BRASIL 2015a) e a Lei da Mediação (BRASIL, 2015b), a aludida Resolução sofreu algumas alterações no texto legal, como exemplo relevante a previsão no art 1ำ, parágrafo único ao dispor que:

$$
\begin{aligned}
& \text { Aos órgãos judiciários } \\
& \text { incumbe, nos termos do } \\
& \text { art. } 334 \text { do Novo Código } \\
& \text { de Processo Civil } \\
& \text { combinado com o art. } 27 \\
& \text { da Lei de Mediação, antes } \\
& \text { da solução adjudicada } \\
& \text { mediante sentença, } \\
& \text { oferecer outros } \\
& \text { mecanismos de soluções } \\
& \text { de controvérsias, em } \\
& \text { especial os chamados } \\
& \text { meios consensuais, como } \\
& \text { a mediação e a } \\
& \text { conciliação, bem assim } \\
& \text { prestar atendimento e } \\
& \text { orientação ao cidadão. } \\
& \text { (CNJ, 2010) }
\end{aligned}
$$

Em junho de 2015, mesmo ano de aprovação do CPC (BRASIL, 2015a) em vigor na legislação pátria, foi aprovada a Lei 13.140, chamada lei da Mediação (BRASIL, 2015b). A referida lei específica sobre a mediação como meio de solução de controvérsias e sobre autocomposição de conflitos no âmbito da administração pública.

É esta lei que define o conceito legal do que é a mediação, conforme consta já no art 1으, parágrafo único: "Considera-se mediação a atividade técnica exercida por terceiro imparcial sem poder decisório, que, escolhido ou aceito pelas partes, as auxilia e estimula a identificar ou desenvolver soluções consensuais para a controvérsia." (BRASIL, 2015b).

No que diz respeito ao âmbito trabalhista, a lei determina em seu art. 42, parágrafo único que a mediação nas relações trabalhistas será regulada por lei própria e sob este aspecto, o poder legislativo instituiu a Lei 13.467 de 13 de Julho de 2017, chamada Lei da Reforma Trabalhista trazendo grandes inovações na CLT, um dos maiores e mais relevante exemplo é a previsão do art. 611-A, ao estabelecer que o convencionado, o acordado, tem prevalência sobre o legislado em determinados casos, podendo então, estes direitos serem objeto de solução através de meios extrajudiciais de solução de conflitos, assunto esse a ser abordado no próximo tópico

\subsection{Mediação e o Direito do Trabalho}

A conciliação e mediação já são buscadas há décadas por vários operadores do direito, como forma não apenas de diminuir os processos judiciais, mas também para possibilitar por uma melhor solução da controvérsia entre as partes na disputa pelo direito.

Mas antes de abordar sobre a mediação, necessário trazer sua diferenciação em relação à conciliação, para melhor compreensão da matéria. A conciliação terá a sua aplicabilidade quando a controvérsia a ser solucionada está relacionada com as partes que não tiveram qualquer vínculo anterior ao problema posto, ou às vezes até tiveram, e justamente pela continuidade reiterada, busca este meio facilitador. É o que acontece com as relações de consumo, por exemplo.

A mediação torna-se diferente, pois a sua utilização decorre justamente do vínculo anterior à controvérsia posta para a solução entre as partes, o que precisa de uma figura imparcial, sem intervenção direta e muito menos opinar, porque a situação colocada possui um histórico, que muitas das vezes até com carga sentimental, como nos casos que envolvem o direito de família e o direito do trabalho.

A Dra. Fernanda Tartuce discorre com maestria sobre o conceito de mediação a partir da figura do mediador como "alguém imparcial atua para facilitar a comunicação entre os envolvidos e propiciar que eles possam, a partir da percepção ampliada dos meandros da situação controvertida, protagonizar saídas produtivas para os impasses que os envolvem" (TARTUCE, 2018, p. 203).

Daí os motivos da eficácia da aplicação da mediação nos casos que lhe são cabíveis, a partir dos ditames previstos atualmente pela Lei no 13.140/2015 (BRASIL, 2015b). Entretanto, muito 
antes da promulgação legal da lei da mediação, a sua aplicação no direito brasileiro foi pioneira no direito do trabalho nos casos envolvendo tanto direitos individuais como coletivos, a exemplo do art. 3 o da Lei no 7.783/89, que trata do direito de greve, prosseguindo com o art. 2을 do Decreto no $1.572 / 1995$ sobre as negociações coletivas e o art. 11 da Lei no 10.192/2001 das negociações prévias e também diante a falta de repasse nos lucros empresariais - art. 4ㅇ a 15 da Lei no 10.101/2000- prosseguindo pela instituição das comissões de conciliação prévia - Lei no 9.958/2000.

Verifica-se a utilização efetiva na Justiça do Trabalho, editou a Resolução no 02/2002 que institucionalizou em primeira instância um Tribunal de Mediação no Brasil e, em 2010, editou a Resolução no 125 por meio do Conselho Nacional da Justiça (CNJ, 2010) oportunidade que ao regulamentar a função do mediador criou os Centros Judiciários de Solução de Conflito e Cidadania - CEJUSC, além da disposição de um código de ética para os mediadores e conciliadores judiciais.

Desta feita a Lei da Mediação vai ao encontro com os princípios do direito do trabalho ao normatizar legalmente a sua aplicação mediação no Brasil, no ano de 2015, através da Lei no 13.140 (BRASIL, 2015a).

Assim, o fato de levar o litígio trabalhista para a mediação, não exime o dever de buscar a preservação do princípio da irrenunciabilidade dos direitos, da continuidade da relação empregatícia, da intangibilidade salarial, da razoabilidade e quiçá da primazia da realidade, como tantos outros, mas sim, buscam resolver da melhor maneira possível, permitindo que as próprias partes cheguem a um denominador comum visando o restabelecimento de um bom convívio social.

Com a adoção do trabalho remoto pelo Judiciário brasileiro, desde a decretação da pandemia em março do corrente ano, levou os tribunais do Brasil a se adaptarem a essa realidade excepcional e adotarem o trabalho em home office, sem prejuízos das atribuições essenciais de garantir a segurança da população e a efetividades das políticas públicas adotadas pelo Estado brasileiro para controle da erradicação do vírus COVID-19.

Com a pandemia, observou-se maior adoção da tecnologia pelos tribunais e o investimento em resolução de conflitos para prevenir a judicialização.
Nota-se que na Justiça do Trabalho, a Recomendação no 01/2020 do Conselho Superior da Justiça do Trabalho, datada de 25 de março de 2020, estabeleceu medidas de continuidade do trabalho judicial por meio digital, por prazo indeterminado, ante a situação emergencial do país. (ARAÚJO, 2020)

Esta recomendação possibilitou que a Justiça Especializada Trabalhista retomasse sua centralidade na vigência da pandemia como destino final de questões diversificadas do direito laboral, tais como revisar acordos e obrigações, bem como andamentos de processos por meio das plataformas digitais; e ainda, a adoção de instrumentos para a mediação e conciliação de conflitos individuais e coletivos em fase processual e fase pré-processual por meios eletrônicos e videoconferência.

Com isso, verificou-se que os magistrados do Trabalho e Desembargadores dos Núcleos Permanentes de Métodos Consensuais de Solução de Disputas (NUPEMEC-JT), e dos Centros Judiciários de Métodos Consensuais de Solução de Disputas (CEJUSC-JT) de 1a e $2^{\text {a }}$ graus, bem como nos órgãos que atuam em regime de plantão judiciário devem engendrar esforços no sentido de promover, com a participação dos interessados, por aplicativos de mensagens eletrônicas ou videoconferência, a mediação e a conciliação de conflitos que envolvam a preservação da saúde e segurança do trabalho em serviços públicos e atividades essenciais previstas no Decreto n. 10.282/20, privilegiando soluções que não inviabilizem a sua continuidade e sempre atentando para cada realidade concreta e localizada de sua jurisdição no segmento profissional e econômico respectivo, com a ressalva que precisam adaptar a estrutura local para viabilizar os acordos on lines. (ARAÚJO, 2020).

Ademais, aos coordenadores dos centros e núcleos de conciliação são recomendados a atuarem como mediadores e conciliadores em âmbito pré-processual, através de contato direto com as partes, seja por e mails, telefones ou plataformas eletrônicas gratuitas, conforme orientação da aludida recomendação do CSJT (Conselho Superior da Justiça do Trabalho), a depender da adaptação do respectivo órgão a essa situação excepcional (ARAUJO, 2020).

Nesse particular, impõe-se atentar para que não transformemos a pandemia em um cenário de violações de direitos constitucionalmente garantidos, a conferir, tão 
somente, proteção às empresas durante a pandemia, ou regalias aos empregadores, num plano de disposição de direitos no momento da concretização dos acordos, ao revés, conforme já evidenciado alhures, os nos polos se encontram seres humanos ou pessoas jurídicas, cuja limitação deve estar em não ferir os direitos sociais garantidos, mesmo diante de uma situação excepcional.

No mesmo diapasão, a Lei n. 14.020 , de 06 de julho de 2020, dispõe sobre o Programa Emergencial de Manutenção do Emprego e da Renda, bem como sobre outras medidas trabalhistas, oriunda da Medida Provisória no 936, regulamentou os acordos de redução proporcional de jornadas e de salários ou de suspensão do contrato de trabalho.

Nos casos de acordos individuais foi criado um limite para empresas com receita bruta, em 2019, superior a $\mathrm{R} \$ 4,8$ milhões. Para essas empresas, a redução de jornada e de salário nos percentuais de $50 \%$ e $70 \%$, ou a suspensão do contrato de trabalho, somente podem ser acordadas individualmente por empregados hipersuficientes (aqueles com diploma em nível superior e salário igual ou maior a duas vezes o teto da Previdência Social, que em 2020 resultava em $\mathrm{R} \$ 12.202,12$, ou por empregados com percepção de até dois salários mínimos). E se o empregado não se enquadrar nesses patamares previstos pela legislação, é possível realizar acordo individual para redução de jornada de $50 \%$ e de $70 \%$, ou acordar a suspensão do contrato de trabalho, se deste acordo não resultar diminuição do valor mensal recebido anteriormente pelo empregado, somando-se para este cálculo o salário reduzido, o valor do Benefício Emergencial (BEm) pago pelo governo e uma ajuda mensal compensatória a cargo da empresa, ou seja, a empresa complementa para evitar a redução dos recebimentos mensais desse empregado. (SOUSA; ARAGÃO; CARNEIRO, 2020).

Essas suspensões dos contratos de trabalho serão regulamentadas, nos termos dos artigos 11 e 12 da Lei 14.020/2020, seja por convenção coletiva de trabalho, acordo coletivo de trabalho, ou mesmo, por acordo individual por escrito entre empregador e empregado, devendo, a proposta de acordo, ser encaminhada ao empregado com a mínima antecedência de dois dias corridos, com a ressalva que para possibilitar a efetivação desses acordos, a empresa terá que pagar ajuda mensal compensatória.

Para aqueles empregados que recebam acima de $\mathrm{R} \$ 2.090,00$ para empresas com receita bruta superior a $R \$$ 4,8 milhões em 2019, ou acima de $\mathrm{R} \$ 3.135,00$ para empresas com receita bruta igual ou inferior a $R \$ 4,8$ milhões, e que não sejam hipersuficientes - para que o acordo individual de redução de jornada de $50 \%$ ou de $70 \%$ seja válido, deverão manter os recebimentos mensais em valor não inferior ao salário antes da redução salarial. Para isso, deverá ser considerada a soma do salário reduzido, do Benefício Emergencial e da ajuda mensal compensatória. As mesmas condições se aplicam à suspensão do contrato de trabalho. (SOUSA; ARAGÃO; CARNEIRO, 2020).

Ademais, essas regras somente se aplicam aos novos acordos, ou seja, com vigência a partir de 07 de julho, já que aqueles realizados sob as regras da Medida Provisória n. 936, regem-se pelas disposições da aludida medida provisória.

Outra relevante alteração trazida pela legislação em comento é a prevalência dos instrumentos coletivos de trabalho sobre os acordos individuais, como regra geral, pois caso haja negociação coletiva após a celebração dos acordos individuais, estes deverão ter aplicabilidade, em relação ao período anterior ao da negociação coletiva, com as ressalvas que o instrumento coletivo prevalecerá, quando conflitar com o disposto no acordo inicial, salvo se no acordo individual for mais benéfico ao trabalhador

Também a lei regulamentou a licença maternidade, no que diz respeito às gestantes $e$ adotantes, uma vez que quando ocorrer o evento caracterizados da licença maternidade para ambas as hipóteses, o empregador deverá comunicar esse fato imediatamente ao Ministério da Economia, para interromper a redução de jornada e salário ou a suspensão do contrato, bem como $o$ pagamento do Benefício Emergencial, sendo que a licença maternidade será paga pelo INSS.

Assim, quando feito o acordo, estas trabalhadoras que têm estabilidade provisória no emprego, desde a confirmação da gravidez até 5 meses após o parto (artigo 10, II, "b", do Ato das Disposições Constitucionais Transitórias $A D C T$ ), iniciará a valer o acordo a partir do término dessa estabilidade provisória, ou seja, após a estabilidade, terão uma garantia 
provisória no emprego de duração equivalente ao período acordado para redução de jornada e salário ou suspensão do contrato de trabalho.

Outra inovação trazida pela lei é que o empregador não pode demitir, sem justa causa, o empregado com deficiência durante o estado de calamidade.

Ressalta-se, por fim, que a lei deixou claro que não se trata de fato do príncipe, previsto no artigo 486 da CLT, que seria o eventual pagamento da indenização ao empregado pela rescisão do contrato de trabalho ficar a cargo do governo responsável ante o estado de calamidade pública decorrente do coronavírus. Nesse sentido:

Art. 29. Não se aplica o disposto no art. 486 da CLT, aprovada pelo Decreto-Lei no 5.452, de 1 o de maio de 1943, na hipótese de paralisação ou suspensão de atividades empresariais determinada por ato de autoridade municipal, estadual ou federal para o enfrentamento do estado de calamidade pública reconhecido pelo Decreto Legislativo $\mathrm{n}$ - 6 , de 20 de março de 2020, e da emergência de saúde pública de importância internacional decorrente do coronavírus, de que trata a Lei $n$ ㅇ 13.979, de 6 de fevereiro de 2020. (BRASIL, 2020).

Espera-se que a Justiça do Trabalho continue a cumprir com o seu mister de prestar o serviço público de justiça social com presteza e eficiência, prevenindo e solucionando os conflitos de sua competência jurisdicional, juntamente com as alterações introduzidas pela Lei 14.020 , para a preservação de empregos e de empresas, com respeito, sobretudo, ao princípio motriz da dignidade.

\section{O potencial da Mediação e da Conciliação durante e pós-pandemia}

À luz da crise sanitária, econômica e social desencadeada pelo COVID 19, a qual tem incutido a todos reflexões de índoles variadas, este trabalho tem por objetivo compartilhar algumas considerações sentidas como úteis ao progresso da política judiciária de tratamento adequado dos conflitos instituída no segmento laboral pela Resolução no 174/16 do CSJT (CSJT, 2016).

A Recomendação $n^{\circ}$ 01, de 25 de março de 2020, evidencia o fortalecimento de uma tendência de o Poder Judiciário reconhecer métodos alternativos/adequados como instrumentos de acesso amplo e efetivo à Justiça. (CSJT, 2020).

É certo que o ato se refere ao momento transitório e de crise, mas não menos verdadeiro é que ele também inova ao permitir a mediação pré-processual de conflitos específicos do trabalho. Se antes a mediação pré-processual já vinha sendo utilizada pela Justiça do Trabalho para compor conflitos coletivos, agora a mediação prévia ao ajuizamento da reclamatória trabalhista passa a ser admitida no período de combate da pandemia.

Tanto melhor será para a sociedade e para a Justiça do Trabalho que, em tempos normais, o caminho para a resolução de conflitos individuais ou coletivos do trabalho seja este: negociação, mediação extrajudicial, mediação judicial/conciliação e judicialização.

Em tempos de crise pandêmica, a diretriz da Recomendação $\mathrm{n}^{\circ}$ 01, de 25 de março de 2020 do Conselho Superior da Justiça do Trabalho (CSJT, 2020), busca soluções criativas e evidencia os altos potenciais de adequação e adaptação dos métodos adequados de resolução de conflitos.

A emergência sanitária advinda do COVID 19 exigiu movimentos rápidos e adaptações diversas.

Foi editada aludida Recomendação $\mathrm{n}$. 01/2020, a qual, entre outras ações, incentivou a utilização de plataformas de videoconferência e o fortalecimento da atuação dos CEJUSCs-JT de primeiro e de segundo graus para preservar a saúde pública e os serviços e as atividades essenciais conforme a realidade concreta do segmento profissional e econômico de cada jurisdição (CSJT, 2020).

Diante de tantas incertezas, parece ser consenso que o mundo não será o mesmo após superada a fase principal de combate à pandemia do coronavírus. Se houver esforço para transformar a pandemia em oportunidade, o Poder Judiciário e a Justiça do Trabalho poderão sair melhores do que entraram na crise e certamente permanecerão as melhores práticas implementadas e bem sucedidas no período da 
crise, de forma seguir o rumo de natural evolução, uma delas certamente será o fortalecimento dos meios alternativos de solução de conflitos.

\section{CONSIDERAÇÕES FINAIS}

Em razão da situação crítica que assola o Poder Judiciário no que se refere a quantidade de processos em andamento, intensificam os estudos e desenvolvimento de métodos e meios extrajudiciais de solução de conflitos.

Nesse contexto, surge na cultura jurídica os meios de solução de conflitos extrajudiciais, baseado na arbitragem, na negociação, mediação e conciliação, com a finalidade precípua de possibilitar que os titulares de direitos e interessados na solução dos litígios passem a não mais depender, para o alcance da solução esperada, apenas da Justiça.

No Brasil, a Justiça do Trabalho, como manifestação direta das relações sociais já andava à frente adotando as práticas de mediação e conciliação quando o assunto era direito coletivo do trabalho, inobstante sempre ter o viés compositivo como marca de efetividade da entrega jurisdicional como um todo; tanto é assim que não se demorou para apresentar à comunidade jurídica, as primeiras providências para atravessar esse período crítico vivenciado na atualidade.

Conforme já acima mencionado, a Recomendação no 1 do CSJT, tem como base as boas e aprovadas experiências de mediação e conciliação nas matérias ligadas ao direito do trabalho coletivo, tanto na fase processual quanto na pré-processual, com a perspectiva de aprofundamento de tais práticas nos conflitos individuais, aliás, essa é a ideia!!

De todo modo, se a Justiça do Trabalho já se encontrava na vanguarda com relação à mediação pré-processual na esfera de conflitos coletivos, agora a mediação prévia também será fortemente aplicada nas demandas individuais, como uma das grandes contribuições neste período da pandemia e seus trágicos efeitos.

A Lei da Mediação, com clara característica de norma de eficácia limitada, dispõe no art. 42, parágrafo único, acima já comentado, que nas relações trabalhistas a mediação deverá ser regulada por lei própria, deixando assim para uma legislação específica tratar sobre o tema (BRASIL, 2015b).

Entretanto, em 2016, o TST (Tribunal Superior do Trabalho) como corte suprema trabalhista, editou a Instrução Normativa de no 39 , dispondo no art. $2^{\circ}$, IV que não se aplica ao processo do trabalho o constante no art. 334 do CPC/15 (BRASIL, 2015a) (audiência de mediação e conciliação) e ainda, no art. 14ㅇ que não se aplica ao Processo do Trabalho o art. 165 do CPC, salvo nos conflitos coletivos de natureza econômica (Constituição Federal, art. 114, §§ 1ㅇe e 2 ㅇ).

Tais previsões geraram inúmeras dúvidas e incertezas com relação a aplicabilidade de mediação nas esferas trabalhistas.

Todavia, com a entrada em vigência da Lei $13.467 / 17$, a função da justiça do trabalho ficou clara ao determinar no art. 652, "f", que as Varas de Trabalho são competentes para homologar acordos extrajudiciais em matérias de competência da justiça do trabalho, além de incorporar ao texto o Capítulo III-A - Do processo de jurisdição voluntária para homologação de acordo extrajudicial - trazendo com isso a segurança jurídica necessária para as partes. (BRASIL, 1943).

Tem-se através do exposto que a regra prevista na instrução normativa de caráter negativo e restritivo ao uso da mediação em matéria trabalhista é relacionada a câmaras de mediação privadas, não se aplicando aos núcleos de solução de conflitos no âmbito dos tribunais, algo que atualmente está se tornando constante, incluindo, como exemplo, a chamada "Semana Nacional da Conciliação", bem como a implantação dos CEJUSC's - Centros de Conciliação da Justiça do Trabalho.

A reforma trabalhista em 2017 que trouxe o art. 611-A ao texto da CLT, trouxe também, o art. 611-B, e observa-se que o primeiro tem caráter positivo, ou seja, o que pode ser objeto de negociação, acordo, entre empregado e empregador, mediante convenção ou acordo coletivo, já o art. 611-B tem caráter negativo, ou seja, o que não pode ser objeto de negociação ou acordo coletivo entre as partes.

Sendo assim a própria CLT, trouxe aspectos que mostram o que pode ou não ser objeto de acordo ou convenção coletivo, prevalecendo para determinadas situações o que for acordado e para outras o que está legislado.

O art. 3o da lei 13.140/15 (Lei da Mediação) dispõe: "Pode ser objeto de mediação o conflito que verse sobre direitos disponíveis ou sobre direitos indisponíveis que admitam transação" (BRASIL, 2015b), ou seja, a lei permite, mesmo o direito sendo indisponível, ser objeto de mediação caso este seja ferido. $O$ que não se 
permite é que o resultado de tal mediação, venha a retirar direitos garantidos.

Para que seja aceito o acordo extrajudicial não pode ter qualquer tipo de coerção de natureza econômica, moral ou física que comprometa o consenso e a validade desse negócio jurídico", afirma, em entrevista ao blog da Mediação Online (MOL), Guilherme Feliciano, juiz do trabalho da 15a Região (Campinas) então Presidente da ANAMATRA (Associação Nacional dos Magistrados do Trabalho).

O que se extrai é que a mediação em conflitos trabalhistas prevista no ordenamento jurídico brasileiro para ter a eficácia plena entre as partes, deve passar por uma homologação na Justiça do Trabalho, onde o Juiz competente avaliará se o que foi mediado não está ferindo direitos indisponíveis e se pode ser objeto de acordo, conferindo assim a segurança necessária.

\section{REFERÊNCIAS}

ARAÚJO, Luis Fernando Cintra. A importância da tecnologia na Justiça do Trabalho em meio a pandemia da COVID-19. Migalhas, São Paulo, maio, 2020. Disponível em: https://www.migalhas.com.br/depeso/326093/aimportancia-da-tecnologia-na-justica-dotrabalho-em-meio-a-pandemia-da-covid-19.

Acesso em: 11 jul.2020.

ARISTÓTELES. Ética a Nicômaco. São Paulo: Abril Cultural, 1987. Livro v.

BAGGIO, Antonio Maria (organizador). 0 Princípio esquecido: exigências, recursos e definições da fraternidade. Vargem Grande Paulista: Editora Cidade Nova, 2009.

BACELLAR, Roberto Portugal. Mediação e Arbitragem. 1. ed. São Paulo: Saraiva, 2012.

BITTAR, Eduardo C. Bianca. Curso de Ética Jurídica. São Paulo: Saraiva, 2002.

BRASIL. Constituição (1988). Constituição da República Federativa do Brasil. Brasília: Senado, Federal, 1988.

BRASIL. Presidência da República. Consolidação das Leis do Trabalho. Decreto-Lei, no 5452, de 01 de maio de 1943. Aprova a Consolidação das Leis do Trabalho. Brasília, 1943. Disponível em: http://www.planalto.gov.br/ccivil_03/decretolei/del5452.htm. Acesso em: 10 jul. 2020.
BRASIL. Presidência da República. Lei no 9.099, de 26 de setembro de 1995. Dispõe sobre os Juizados Especiais Cíveis e Criminais e dá outras providências. Brasília, $1995 . \quad$ Disponível em: http://www.planalto.gov.br/ccivil 03/leis/19 099.htm. Acesso em: 06 jul. 2020.

BRASIL. Presidência da República. Lei no 11.419, de 19 de dezembro de 2006. Dispõe sobre a informatização do processo judicial; altera a lei $n$. 5.869, de 11 de janeiro de 1973- Código de Processo Civil e dá outras providências. Diário Oficial da União, Brasília, 20 dez. 2006. Disponível

em: https://legislacao.presidencia.gov.br/atos/?t ipo $=$ LEI\&numero $=11419 \& a n o=2006 \&$ ato $=d 89 \mathrm{gXR}$ q5kMRpWTa78. Acesso em: 11 jul. 2020.

BRASIL. Presidência da República. Lei no 13.105, de 16 de março de 2015. Dispõe sobre a mediação entre particulares como meio de solução de controvérsias e sobre a autocomposição de conflitos no âmbito da administração pública; altera a Lei no 9.469, de 10 de julho de 1997, e o Decreto no 70.235, de 6 de março de 1972; e revoga o § 2 ㅇ do art. 60 da Lei no 9.469, de 10 de julho de 1997. Brasília, 2015a. Disponível em: http://www.planalto.gov.br/ccivil_03/_Ato20152018/2015/Lei/L13140.htm. Acesso em: 06 jul. 2020.

BRASIL. Presidência da República. Lei no 13.140, de 26 de junho de 2015. Dispõe sobre a mediação entre particulares como meio de solução de controvérsias e sobre a autocomposição de conflitos no âmbito da administração pública; altera a Lei no 9.469, de 10 de julho de 1997, e o Decreto no 70.235, de 6 de março de 1972; e revoga o § 20 do art. 60 da Lei no 9.469, de 10 de julho de 1997. Brasília, 2015b. Disponível em: http://www.planalto.gov.br/ccivil_03/_Ato20152018/2015/Lei/L13140.htm. Acesso em: 06 jul. 2020.

BRASIL. Presidência da República. Lei no 14.020, de 06 de fevereiro de 2020. Dispõe sobre o Programa Emergencial de Manutenção do Emprego e da Renda; dispõe sobre medidas complementares para enfrentamento do estado de calamidade pública reconhecido pelo Decreto Legislativo no 6, de 20 de março de 2020, e da 
emergência de saúde pública de importância internacional decorrente do coronavírus, de que trata a Lei no 13.979, de 6 de fevereiro de 2020; altera as Leis nos 8.213 , de 24 de julho de 1991, 10.101, de 19 de dezembro de 2000, 12.546, de 14 de dezembro de 2011, 10.865, de 30 de abril de 2004, e 8.177, de 10 de março de 1991; e dá outras providências. Brasília, 2020. Disponível em:

http://www.planalto.gov.br/ccivil_03/_Ato20192022/2020/Lei/L14020.htm. Acesso em: 08 jul. 2020.

BRASIL. Ministério da Economia. Benefícios acima do mínimo têm reajuste de $5,45 \%$. Brasília: Governo do Brasil, 2021.

CALMON, Petrônio. Fundamentos da mediação e da conciliação. Rio de Janeiro: Forense, 2007.

CARMONA, C. A. Arbitragem e processo: um comentário à lei 9307/96. São Paulo: Atlas, 2009.

CAVALCANTE, M. A. L. Comentários à Lei 13129/2015 (Reforma da Lei de Arbitragem). Disponível em: https://www.dizerodireito.com.br/2015/05/com entarios-lei-131292015-reforma-da.html. Acesso em 08 jul. 2020.

CNJ. Conselho Nacional de Justiça. Resolução 125, de 29 de novembro de 2010. Dispõe sobre a Política Judiciária Nacional de tratamento adequado dos conflitos de interesses no âmbito do Poder Judiciário e dá outras providências. Brasília, 2010. Disponível em: https://atos.cnj.jus.br/files/resolucao_125_29112 010_03042019145135.pdf. Acesso em: 08 jul. 2020.

CSJT. Conselho Superior da Justiça do Trabalho. Resolução $\mathbf{N}^{\circ}$ 174, de 30 de setembro de 2016. Dispõe sobre a política judiciária nacional de tratamento adequado das disputas de interesses no âmbito do Poder Judiciário Trabalhista e dá outras providências. Brasília: Justiça do Trabalho, $2016 . \quad$ Disponível em: http://www.csjt.jus.br/c/document_library/get_fi le?uuid=235e3400-9476-47a0-8bbbbccacf94fab4\&groupld=955023. Acesso em: 10 jul. 2020.

CSJT. Conselho Superior da Justiça do Trabalho. Recomendação CSJT.GVP N 01, de 25 de março de 2020. Recomenda a adoção de diretrizes excepcionais para o emprego de instrumentos de mediação e conciliação de conflitos individuais e coletivos em fase processual e fase préprocessual por meios eletrônicos e videoconferência no contexto da vigência da pandemia do Novo Coronavirus (COVID-19). Brasília: CSJT, 2020. Disponível em: http://www.csjt.jus.br/documents/955023/7648 579/CSJT-VP-Recomend-MedCovid.pdf/cbb38f05-a701-db4c-2478c80eecc713b3?t=1585315854390. Acesso em: 10 jul. 2020.

DECLARAÇÃO UNIVERSAL DOS DIREITOS HUMANOS. Macrotemas, 1948. Disponível em: http://www.dhnet.org.br/direitos/deconu/textos /integra.htm. Acesso em 01 jul. 2020.

ERDELYI, Maria Fernanda. "Setor de conciliação em São Paulo abre portas da Justiça". Conjur, 13 dez. $2005 . \quad$ Disponível em: $\quad$ www.conjur.com.br/2005-dez13/setor_conciliacao_sp_abre_portas_justiça. Acesso em 28 jul. 2020.

GUILHERME, Luiz Fernando do Vale de Almeida. Manual dos MESCs: meios extrajudiciais de solução de conflitos. Barueri/SP: Manole, 2016.

HESSE, Konrad. A força normativa da constituição. Porto Alegre: Sergio ANTONIO Fabris Editor, 1991.

HINKELAMMERT, Franz. Crítica à razão utópica. São Paulo: Editora Paulinas, 1988.

LAKATOS, Eva Maria; MARCONI, Marina de Andrade. Metodologia científica. 3. ed. São Paulo: Atlas, 2000.

NUNES, Antonio Carlos Ozôrio. Manual de mediação: guia prático da autocomposição. São Paulo: Saraiva, 2016.

PASSOS, José Joaquim Calmon de. Direito, poder, justiça e processo: julgando os que nos julgam. Rio de Janeiro: Revista Forense, 2003, p.37.

PEREIRA, Clovis Brasil. Conciliação e Mediação no Novo CPC. Disponível em: http://www.conima.org.br/arquivos/4682.

Acesso em: 16 jul. 2020. 
REALE, Miguel. Variações sobre a normatividade. O Estado de São Paulo, São Paulo, 04 de junho de 2005.

SANTOS, Boavenura de Sousa. Por uma Concepção Multicultural dos Direitos Humanos. Revista Crítica de Direitos Sociais, n. 48, jun. 1997. DOI https://doi.org/10.1590/S0102$\underline{64451997000100007 .}$

SARLET, Ingo Wolfgang. A eficácia dos direitos fundamentais: uma teoria geral dos direitos fundamentais na perspectiva constitucional. 11 ed. Porto Alegre: Livraria do Advogado, 2012.

SILVA, José Afonso. Curso de direito constitucional positivo. 16 ed. São Paulo: Malheiros, 1999.

SILVA, José Afonso. Comentário contextual à Constituição. 5 ed. São Paulo: Saraiva, 2008.

SOUSA, Sylvia Lorena T.; ARAGÃO, Camila Jardim; CARNEIRO, Pablo Rolim. As novidades da Lei 14.020 em relação à MP 936. Consultor Jurídico, 07 jul. 2020. Disponível em: https://www.conjur.com.br/2020-jul-07/cninovidades-lei-14020-relacao-mp-936. Acesso em: 12 jul. 2020.

STJ. Superior Tribunal de Justiça. Ministro Reynaldo fala do princípio da fraternidade em debate sobre direito e futuro na crise do vírus. $2020 . \quad$ Disponível em: http://www.sti.jus.br/sites/portalp/Paginas/Com unicacao/Noticias/Ministro-Reynaldo-fala-doprincipio-da-fraternidade-em-debate-sobredireito-e-futuro-na-crise-do-virus.aspx. Acesso em 01 jul. 2020.

TARTUCE, Fernanda. Mediação nos conflitos civis. 4. ed. Rio de Janeiro: Forense. São Paulo: Método, 2018.

WATANABE, Kazuo. Mediação como política pública social e judiciária: mediação e Conciliação. Revista do Advogado, São Paulo, n. 123, 2014. 